\title{
NILAI-NILAI SPIRITUAL SUFISTIK QASIDAH BURDAH DALAM MENINGKATKAN RELIGIUSITAS
}

\author{
ASEP SOLIKIN \\ Dosen Bimbingan dan Konseling Fakultas Keguruan dan Ilmu Pendidikan \\ Universitas Muhammadiyah Palangkaraya \\ Email : asep.solikin@yahoo.com
}

\begin{abstract}
In the perspective of the development of one's religiosity can be developed through touches the other side that can bring spiritual and inner shades religious person. It can be touched by some form. The forms that try to offer in this study is about Qasidah Burdah (QB) developed at boarding school and in some majlistaklim in public life can be categorized as an internalization of values in the media application using music as a medium.

Researchers used a qualitative approach in this research to complete the study. Researchers believe using this approach because the problem in this study is very holistic, complex, dynamic and full of meaning that is not possible data on the social situation captured by quantitative research methods such as test instrument. Moreover, the authors intend to understand the social situation in depth, find the strategy pattern, hypotheses and theories associated with this research study.

The content of the values of Sufism in Qasidah Burdah still have suitability (relevance) to the teachings of Islam in terms of both goals (for the human form in order to be a perfect human being (insan kamil) as a servant of God and as a vicegerent on earth) and material (faith, Sharia and morals). therevore, Qasidah Burdah can be used as a reference or references in the individual maturation process, especially in Indonesia.
\end{abstract}

Keywords : spiritual, religious

\section{ABSTRAK}

Seseorang dalam perspektif perkembangan religiusitas dapat dikembangkan melalui sentuhansentuhan sisi lain yang bisa menghidupkan spiritual dan nuansa bathin keberagamaan seseorang. Hal itu dapat disentuh dengan beberapa bentuk. Bentuk yang coba ditawarkan dalam kajian ini adalah tentang Qasidah Burdah (Pengajian QB) yang dikembangkan di pondok pesantren dan di beberapa majlis taklim dalam kehidupan masyarakat dapat dikategorikan sebagai internalisasi nilai yang dalam penerapannya menggunakan media musik sebagai medianya.

Peneliti menggunakan pendekatan kualitatif dalam penelitian ini untuk menyelesaikan penelitian tersebut. Peneliti berkeyakinan dengan menggunakan pendekatan tersebut karena masalah dalam penelitian ini sangat holistik, kompleks, dinamis dan penuh makna sehingga tidak mungkin data pada situasi sosial tersebut dijaring dengan metode penelitian kuantitatif dengan instrument seperti test. Selain itu penulis bermaksud memahami situasi sosial secara mendalam, menemukan pola strategi, hipotesis dan teori yang terkait dengan kajian peneltian ini.

Kandungan tentang nilai-nilai tasawuf dalam Qasidah Burdah tersebut masih memiliki kesesuaian (relevansi) dengan ajaran-ajaran Islam baik dari segi tujuan untuk membentuk manusia supaya menjadi manusia yang sempurna (insan kamil) sebagai hamba Allah serta sebagai khalifah di muka bumi ini, maupun materi (akidah, syariah dan akhlak). Oleh sebab itu, qasidah burdah bisa dijadikan sebagai salah satu acuan ataupun rujukan dalam proses pematangan individu tersebut khususnya di Indonesia.

Kata kunci : spiritualitas, religiusitas 


\section{PENDAHULUAN}

Ilmuwan dalam bidang psikologi, yang salah satunya bernama Thomas Agosin pada sekitar tahun 1970-an dan 1980-an memasukan unsur spiritual pada situasi klinis. Mereka, sebagaimana Cafh, juga mendorong para pengikutnya untuk melihat yang mistikal, yang transenden, yang menakjubkan dalam kehidupan sehari-hari. Agosin membawa kesadaran yang membuka mata ini ke dalam praktik klinis. la mengembangkan teknik mengatasi masalah mental, psikosis, hingga depresi, dengan mengandalkan kepekaan spiritualnya. la percaya bahwa agama mencari keutuhan, adalah akar dari banyak penyakit mental dan ia memperlakukan pasiennya dalam kerangka spiritual ini. Sebagai contoh, ia memperlakukan pasiennya yang mengidap depresi yang sangat parah. la tidak beragama, satu-satunya kesenangan baginya adalah makan dan mimun sebanyak mungkin untuk menghilangkan kegalauannya, mimpi-mimpi buruk yang selalu menghantuinya dan lain sebagainya.

Perkembangan religiusitas seseorang dapat dikembangkan melalui sentuhan-sentuhan sisi lain yang bisa menghidupkan spiritual dan nuansa bathin keberagamaan seseorang. Hal itu dapat disentuh dengan beberapa bentuk. Bentuk yang coba ditawarkan dalam tulisan ini adalah tentang Qasidah Burdah (selanjutnya disingkat denga QB). Pengajian QB yang dikembangkan di pondok pesantren dan di beberapa majlis taklim dalam kehidupan masyarakat dapat dikategorikan sebagai internalisasi nilai yang dalam penerapannya menggunakan media musik sebagai medianya. Di luar praktek pendidikan, musik sering dijadikan sebagai media penyeimbang antara domain kognisi, afeksi dan psikomotor. Praktek ini sering dilakukan di dalam bidang kesehatan, khususnya dalam teknik psikoterapi. Dengan "mencontoh" teknik tersebut, pondok pesantren berusaha mensinkronisasikan proses internalisasi nilai dengan media musik sebagai komplemennya. Berdasarkan observasi sementara, pengajian di pondok pesantren yang dilengkapi dengan musikalisasi dianggap sebagai salah satu "model" internalisasi. Lebih dalam lagi, selanjutnya upaya mengkaji proses internalisasi ini, secara operasional dapat diungkapkan beberapa hal yang berkenaan dengan efikasi musikalitas dari sistem pangajian di dalamnya.

Pada fakta lain, QB sangat dikenal di kalangan kaum tradisional maupun modern, untuk di kalangan tradisional biasanya dibacakan di langgar-langgar, istilah tempat kecil untuk shalat di Palangkaraya dan pesantren-pesantren salafiyah. Adapun untuk kalangan modern secara kosmopolitan bahwa popularitas QB telah mencakup lima benua; Asia, Afrika, Amerika, Eropa dan Australia (Manshur, 2007:240). Beberapa dekade yang lalu QB seiring dengan perkembangan zaman, sering dibacakan, dihafal secara berjamaah oleh para santri pesantren tradisional, jamaah tajug, mushalla, langgar dan tempat-tempat riyadlahan lainnya. Namun setelah sekian lama masa pun semakin berkembang, anak-anak langgar, tajug dan lain-lain itu semakin terkikis oleh budaya modernisme yang merasuk dan memporakporandakan nilai-nilai ruhiyah di wilayah pedesaan saat ini.

Berdasarkan fenomena di atas, maka kajian ini sebagai upaya menuju langkah-langkah sosialisasi kembali terhadap nilai-nilai yang terkandung dalam QB kepada warga pesantren 
(santri, masyarakat sekitar pesantren) dan masyarakat umum yang pada awalnya membaca, menghafal hingga menggali nilai-nilai $Q B$ tersebut. Adapun pola sosialisasi yang ditanamkan melalui metode pengajian yang dikemas lewat musikalisasi QB ini diharapkan mampu menyentuh ruhani para pendengar, dan ter adinya perubahan sikap, perilaku dan akhlak santri, lalu proses internalisasinya dilaksanakan berdasarkan pemahaman tingkatan pengajian yang tersedia.

Ulama tasawuf cenderung menganggap bahwa musik hukumnya halal. Landasan hukum yang digunakan merujuk pada Q.S. al-Maidah:87 : "Hai orangorang yang beriman, janganlah kamu mengharamkan apa-apa yang baik yang telah Allah halalkan bagimu, dan janganlah kamu melampaui batas. Seseungguhnya Allah tidak menyukai orang-orang yang melampaui batas". Asumsi dasar yang digunakan oleh ulama tasawuf adalah: 1) Musik tidak diharamkan baik oleh Allah swt maupun Nabi s.a.w. secara tekstual, 2) Ada beberapa hadits yang mengkisahkan Nabi s.a.w. memperkenankan permainan musik, 3) Jika musik digolongkan sebagai Lahw (senda gurau) yang diharamkan, maka semua hal yang bersifat duniawi juga haram hukumnya. Dalam Q.S. Muhammad: 36: "Sesungguhnya kehidupan dunia ini hanyalah permainan (la'b) dan senda gurau (lah-w)" (al-Qardhawy, 2001:72).

Qasidah Burdah adalah karya seorang penulis yang bergelar seniman dan ilmuwan, bernama Imam al-Bushiry, seorang ulama sufi, sehingga isi dari Qasidah Burdah adalah pikiranpikiran tentang ajaran tasawuf. Pikiran-pikiran alBushiry ini dikategorikan sebagai ilmu yang membicarakan sejarah kesusastraan.
Dalam kaitannya dengan jenis musikalitas Qasidah Burdah, dapat dikemukakan bahwa Qasidah Burdah dimasukan ke dalam jenis madchun-naby yang mengandung taranum musiqa atau senandung musik 'arudly dengan bahar (wazan/segmen) al-basith menunjukkan arti "terbentang/terpapar" karena memiliki jenis musik yang "memanjang datar" sehingga irama dari bait ke bait memberikan corak yang hampir sama nada-nadanya, kecuali dalam segmen bait tertentu (www.westjavainvest.com.in)

Qasidah Burdah dapat dikategorikan sebagai karya sastra Islam karena di dalam kandungan teksnya memuat cerita biografi Nabi dan berisi ajaran-ajaran tasawuf yang dapat dimanfaatkan oleh manusia untuk menjadi pijakan kehidupan spiritualnya. Oleh karena itu, dipandang perlu untuk memahami esensi Qasidah Burdah sebagai karya sastra Islam yang mengandung juga musicalitas sufistik. Hal ini sebagaimana pandangan Nasr (2003) dalam Manshur didasarkan pada asumsi bahwa sastra adalah cermin spiritualitas Islam. Asumsi ini berimplikasi sebagaimana pandangan Nasr (2003) dalam. Manshur didasarkan pada asumsi bahwa sastra adalah cermin spiritualitas Islam. Asumsi ini berimplikasi pada satu pandangan yang mengatakan bahwa Islam dapat dipandang sebagai suatu budaya dan peradaban (lihat G.E. von Grunebaum dalam Waardenburg, 1993: 87) karena di dalam agama, ini terdapat banyak entitas budaya sebagai hasil penafsiran atas ajaran-ajarannya. Entitas budaya itu, antara lain, tercermin dalam bahasa dan karya-karya sastra Arab, terutarna puisinya, yang sebagian besar memuat tema-tema Islam yang menggambarkan kehidupan bangsa muslim Arab. 
Qasidah Burdah terdiri dari 160 bait yang ditulis dengan gaya bahasa atau uslub yang menarik, lembut dan elegan. Imam al-Busiri menterjemahkan kehidupan Nabi Muhammad SAW kedalam bentuk bait-bait puisi yang sangat indah. Dengan bahasa yang begitu indah, Imam al-Busiri telah berhasil menanamkan kecintaan dan kasihnya umat Islam kepada Junjungan Besar Nabi Muhammad saw dengan lebih mendalam. Selain dari rasa kecintaan dan kasih yang mendalam terhadap Nabi saw, nilai-nilai sastera, sejarah dan moral turut terkandung dalam qasidah tersebut.

Qasidah Burdah yang menjadi tema utama dalam karya al-Busiri itu adalah merujuk kepada jubah yang dipakai oleh Nabi Muhammad saw. Burdah milik Nabi Muhammad saw ini telah diberikan kepada Ka'ab bin Zuhair bin Abi Salma, seorang penyair terkenal Muhadramin (penyair dua zaman yaitu Jahiliyyah dan Islam). Riwayat pemberian burdah oleh Rasulullah saw kepada Ka'ab bin Zuhair bermula apabila Ka'ab sentiasa menggubah syair yang mengejek-ejek Nabi saw dan para sahabat. Karena rasa jiwanya terancam, ia lari bersembunyi untuk melindungi diri dari kemarahan para sahabat. Ketika terjadi penaklukan Makkah, saudara Ka'ab yang bernama Bujair bin Zuhair mengutus surat kepadanya yang isinya antara lain menganjurkan Ka'ab agar pulang bertaubat dan berjumpa Rasulullah saw.

\section{METODOLOGI}

Peneliti menggunakan pendekatan kualitatif dalam penelitian ini untuk menyelesaikan penelitian tersebut. Peneliti berkeyakinan dengan menggunakan pendekatan tersebut karena masalah dalam penelitian ini sangat holistik, kompleks, dinamis dan penuh makna sehingga tidak mungkin data pada situasi sosial tersebut dijaring dengan metode penelitian kuantitatif dengan instrument seperti test. Selain itu penulis bermaksud memahami situasi sosial secara mendalam, menemukan pola strategi, hipotesis dan teori yang terkait dengan kajian ini.

Analisis data dalam penelitian ini berlangsung sebelum memasuki lapangan, selama di lapangan dan sampai setelah selesai di lapangan. Penelitian ini telah melakukan analisis data sebelum peneliti memasuki lapangan. Analisis dilakukan terhadap data hasil studi pendahuluan dan data sekunder yang digunakan untuk menentukan fokus penelitian. Namun fokus penelitian ini masih bersifat sementara dan berkembang setelah peneliti masuk ke lapangan. Proses yang diakukan adalah kepekaan peneliti dalam melihat fenomena yang terjadi selama ini tentang religiusitas masyarakat. Adapun analisis data selama di lapangan, peneliti menganalisis data, memilih tahapan analisis data model Spradley, dimana proses peneliti ketika memasuki lapangan, mulai dengan menetapkan informan kunci "key informan" yang merupakan informan yang dipercaya mampu membukakan pintu pada objek penelitian, dalam hal ini adalah para pengakar QB dan peserta Halaqoh QB berasal dari masyarakat dari berbagai kelompok dan kalangan.

Dalam pengujian keabsahan data, metode dalam penelitian ini Nilai Kebenarannya adalah Validitas Internal, Aspek Penerapannya adalah Validitas Eksternal, Aspek Konsistensi merupakan Reliabilitas dan Aspek Naturalis berkaitan dengan objektifitasnya. 
Bermacam-macam uji kredibilitas adalah sebagai berikut :

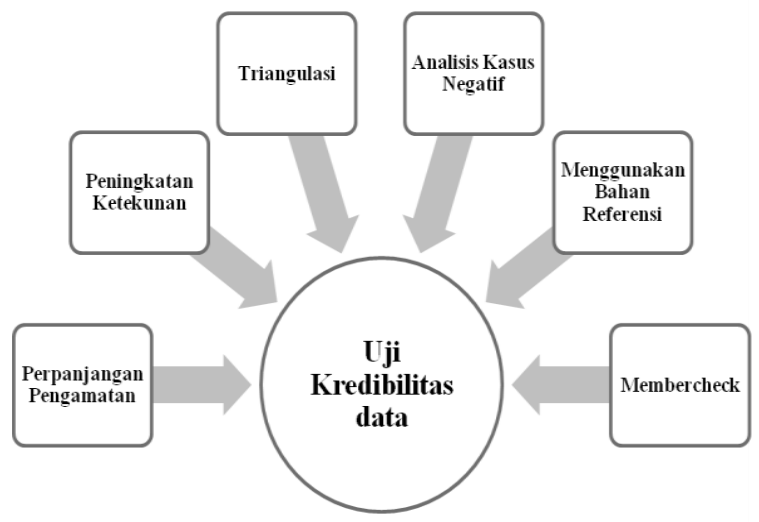

HASIL DAN PEMBAHASAN

\section{Seni Nilai Qasidah Burdah}

Seni atau kesenian (Khoirun Rosyadi: 2004:124) adalah salah satu unsur dari kebudayaan. Menurut Aristoteles, kesenian pada dasarnya adalah untuk mendidik perasaan manusia supaya menjadi halus dan peka dalam menghadapi rangsangan dan tantangan. Pada garis besarnya kesenian dapat dibedakan menjadi beberapa hal berikut:

a. Seni sastra atau kesusastraan, seni dengan alat bahasa

b. Seni musik, seni dengan alat bunyi atau suara

c. Seni tari, seni dengan alat gerakan

d. Seni rupa, seni dengan alat garis, bentuk, warna dan lain sebagainya

e. Seni drama atau teater, seni dengan alat kombinasi sastra, musik, tari atau gerak dan rupa (Endang Saifuddin Anshari, 1992).

Hidup tanpa seni adalah kasar begitu pernyantaan Mukti Ali (mantan Menteri Agama), dan sastra adalah salah satu cabang dari kesenian. Sebagai salah satu cabang dari kesenian maka sastra memiliki pengaruh terhadap kehidupan manusia. Hal ini dikarenakan sastra merangsang manusia untuk lebih memahami, dan menghayati kehidupan, sastra bukan merumuskan dan mengabstrasikan kehidupan kepada manusia tetapi menampilkannya. Menurut Norman Podhoretz yang dikutip oleh Jabrohim "sastra dapat memberi pengaruh yang sangat besar terhadap cara berfikir seseorang mengenai hidup, mengenai baik buruk, mengenai benar salah, mengenai cara hidup sendiri serta bangsanya".

Ciri dari karya sastra yang sangat khas dan penting adalah fungsinya sebagai sistem komunikasi. Memang benar karya sastra dihasilkan melalui imajinasi dan kreativitas, sebagai hasil kontemplasi secara individual, akan tetapi karya sastra juga ditujukan untuk menyampaikan suatu pesan kepada orang lain, sebagai komunikasi (Nyoman Kutha Ratna)

Sastra dan agama juga tidak dapat dipisahkan, hal ini tercermin dari bagaimana Allah menyampaikan ajaran-Nya berupa agama Islam kepada manusia melaui Rasul-Nya dalam bentuk Al-Qur'an yang dikemas dalam bahasa dan sastra yang sangat indah. Kemudian Rasul menyampaikannya dengan menggunakan bahasa yang baik dan indah dengan dihiasi gaya sastra yang indah pula (Akhmad Muzakki, 2006).

Sastra dalam perspektif agama juga merupakan suatu alat yang sangat baik untuk menyampaikan ajaran agama. Di samping berbagai manfaat di atas sastra juga dapat dipakai menjadi alat pendidikan. Salah satu wujud sastra ialah syair/syi'ir. Syair/syi'ir ialah "suatu kalimat yang sengaja disusun dengan menggunakan irama dan sajak yang 
mengungkapkan tentang khayalan atau imajinasi yang indah" (E.M. K. Kaswardi , 1993).

Kandungan Qasidah Burdah yang sejatinya memiliki nilai pendidikan Islam ialah tentang ajaran-ajaran pengendalian hawa nafsu. Hal ini tertuang dalam bait 18 yang berbunyi : Nafsu bagaikan anak bayi, jika engku membiarkannya ia akan terus ingin menyusu dan jika engkau menyapihnya ia akan berhenti.

\section{Spiritualitas Qasidah Burdah}

Secara bahasa spiritual berasal dari kata spirit atau spiritus yang mengandung pengertian: nafas, udara, angin, semangat, kehidupan, pengaruh, antusiasme, atau nyawa yang menyebabkan hidupnya seseorang. Kata spiritus dipergunakan untuk bahan bakar dari alkohol, di Barat minuman anggur sering juga disebut sebagai spirit dalam arti minuman pemberi semangat. Dari serangkaian arti diatas kata spirit jelas mengandung makna kiasan yaitu semangat atau sikap yang mendasari sebuah tindakan, karena sebuah tindakan manusia banyak sekali yang mendasarinya, sedangkan spirit adalah dapat menjadi salah satunya.

Kata spirit juga digunakan untuk menyebut sebuah entitas atau makhluk immaterial, atau sesuatu bentuk energy yang hidup, nyata, meski kasat mata, tidak memiliki badan fisik. Entitas makhluk hidup ini ada dua, yang bersifat ketuhanan menurut aslinya dan memiliki cirri karakteristik kemanusiaan, atau juga dipergunakan untuk makhluk halus atau hantu.

Sedangkan menurut Burkhardt spiritualitas dalam kehidupan seorang individu meliputi aspekaspek berikut:
1. Berhubungan dengan sesuatu yang tidak diketahui atau ketidakpastian dalam kehidupan.

2. Menemukan arti dan tujuan hidup

3. Menyadari kemampuan untuk menggunakan sumber dan kekuatan dalam diri sendiri.

4. Mempunyai perasaan keterikatan dengan diri sendiri dan dengan Yang Maha Tinggi.

Aspek-aspek spiritual dalam pandangan menurut Stoll terdapat hubungan yang terus menerus dan tidak boleh terputus. Selain istilah diatas terdapat beberapa istilah penting yang terkait yaitu konsep spiritual dan kebutuhan spiritual. Dalam pandangannya konsep spiritual adalah konsep dimana seseorang berupaya mempertahankan keharmonisan atau keselarasan dengan dunia luar, mendapatkan kekuatan saatsaat kritis, ketahanan diri dan mencari jati diri dan kesadaran diri.

Efek spiritualitas nilai-nilai utama Qasidah Burdah bersifat komprehensif karena dalam spiritualitasnya menyentuh semua aspek kehidupan seseorang termasuk kontribusinya bagia agama atau komunitas karena spiritualitas mewarnai, jika bukannya menentukan inti seseorang. Cahaya spiritual akan mengakibatkan munculnya perhatian yang luar biasa. Tidak sulit membuat argumen bahwa di dalam semua spiritualitas yang tetap bertahan pada saat ini, cahaya akan mengakibatkan munculnya perhatian yang sama.

Prinsip-prinsip qasidah burdah ditinjau dari sisi psikologis mampu meningkatkan seseorang dari pelafalnya dan pembacanya akan memiliki kecerdasan spiritual yang baik. Hal ini menunjukkan bahwa dengan memiliki kecerdasan spiritual memiliki kebermaknaan yang lebih dari 
yang lainnya. Ini menunjukkan bahwa makna dan hakikat kehidupan yang kita jalani dan ke manakah kita akan pergi. Jika merujuk pada agama, pada awal penciptaan manusia, Tuhan meniupkan roh atau napas kehidupan kepada manusia. Berarti roh kita adalah sesuatu yang membuat kita hidup.

Manusia dalam dimensi keberagamaan sebenarnya membutuhkan spiritualitas sebagai bagian dalam hidupnya pada proses penemuan makna hidup. Kebutuhan manusia akan spiritualitas didasarkan pada;

a. Kebutuhan untuk mempertahankan atau mengembalikan keyakinan dan memenuhi kewajiban agama serta kebutuhan untuk mendapatkan maaf atau pengampunan, mencintai, menjalin hubungan, penuh rasa percaya dengan Tuhan.

b. Kebutuhan untuk mencari arti dan tujuan hidup, kebutuhan untuk mencintai dan dicintai serta rasa keterikatan.

c. Kebutuhan untuk memberikan dan mendapatkan maaf

\section{Kematangan Religiusitas Individu}

Peningkatan kualitas religiusitas manusia merupakan proses internalisasi ilmu pengetahuan dan pemahaman secara komprehensif mengenai nilai-nilai ajaran agama dan penghayatan yang baik tentang Sang Pencipta sebagai sumber nilai tertinggi bagi sistem ajaran agama, maupun ajaran agama yang ideal dalam semua segi kehidupan duniawi. Pengetahuan, pemahaman dan penghayatan tergadap nilai-nilai ajaran agama secara komprehensif dan benar akan membentuk sikap dan prilaku yang religius.
Oleh karena itu setidaknya terdapat lima hal seseorang itu dapat dikatakan meningkat religiusitasnya dengan lima indikator. Kelima indikator tersebut dapat dicapai dengan sebuah usaha dan bimbingan secara terus menerus, dan dengan bantuan orang lain. Dengan bimbingan yang benar maka seseorang akan dapat mencapai kematangan dan peningkatan religiusitas yang baik. Adapun dimensi religiusitas dapat dijelaskan pada hal-hal di bawah ini;

a) Dimensi keyakinan (the ideological dimension, religious belief), yaitu kepercayaan yang diyakini individu terhadap agama yang menjadi anutannya;

b) Dimensi peribadatan atau praktik agama (the ritualistic dimension, religious practice), yaitu dimensi yang mengetengahkan tentang ritual dan aktivitas yang dilakukan sebagai pengokoh keyakinan dalam keagamaan;

c) Penghayatan (the experiential dimension, religious feeling), yaitu pemahaman, pemikiran yang mendalam (deep thinking) terkait dengan anutan yang menjadi keyakinan yang biasanya ditampakkan dalam perilaku kehidupan seharihari;

d) Pengalaman (the consequential dimension, religious effect), yaitu aktualisasi kulminasi dari keseluruhan pemahaman yang mendalam terkait dengan religi tadi yang diejewantahkan dalam aktivitas nyata, baik interaksi dengan manusia, lingkungan dan juga dengan Rabbny

e) Pengetahuan beragama (the intellectual dimension, religious knowledge), dimensi ini lebih menonjolkan aspek keberwawasan individu terhadap keyakinan yang dianutnya. 


\section{KESIMPULAN DAN SARAN}

\section{Kesimpulan}

Pendidikan adalah suatu proses yang memiliki tujuan tertentu, dan demi tercapainya tujuan yang diinginkan tersebut maka terdapat berbagai materi pendidikan yang harus diajarkan, demikian halnya dengan pendidikan Islam yang memiliki tujuan untuk mencetak manusia supaya menjadi manusia yang beriman dan bertakwa kepada Allah sehingga mampu mengemban amanat sebagai hamba Allah sekaligus khalifah di muka bumi ini. Demi tercapainya tujuan tersebut maka dalam pendidikan Islam terdapat materimateri yang harus diajarkan. Materi-materi tersebut ialah aqidah (keimanan), syariah serta akhlak yang didasarkan atas Al-Qur'an serta Sunnah Nabi.

Penelitian ini setidaknya ada beberapa hal yang dapat disimpulkan;

1. Qasidah Burdah terkandung didalamnya nilai-nilai spiritual tentang aqidah, syariah dan akhlak, yang mana nilai-nilai tersebut bisa dijadikan sebagai acuan dan penyampaian materi dalam pendidikan kepribadian seseorang untuk menjadi insan yang lebih bertakwa. Cakupan tentang materi aqidah dalam Qasidah Burdah ialah rukun iman yang enam, materi syariah mencakup tentang shalat, puasa, doa, dan jihad, sedangkan cakupan materi tentang akhlak ialah akhlak kepada Allah, Rasul serta akhlak kepada diri sendiri.

2. Dimensi religiusitas individu pada hakekatnya dapat dikategorikan dalam dua komponen utama, yaitu : (a) manusia sebagai makhluk Sang Pencipta; (b) sikap yang mendorong perkembangan dari perikehidupan manusia berjalan ke arah dan sesuai dengan kaidah-kaidah keyakinan. Oleh karena itu religiusitas individu, setelah dengan intens mengikuti kegiatan Qasidah Burdah akan dapat terlihat kematanganya terutama pada nilai-nilai spiritualitasnya pada lima dimensi berikut; Dimensi keyakinan, dimensi peribadatan atau praktik agama, penghayatan, pengalaman, dan pengetahuan beragama.

\section{Saran}

Berdasarkan temuan-temuan di atas maka di sini ada dua hal yang ingin penulis kemukakan dalam bentuk saran, yaitu ditujukan kepada:

1. Peminat karya sastra: untuk tidak hanya terbius dengan keindahan bahasa dalam sebuah karya sastra, akan tetapi harus lebih menggali pesan-pesan yang terkandung di dalamnya, karena dalam karya sastra sarat akan pesan-pesan moral atau pendidikan yang ingin disampaikan oleh pengarangnya.

2. Pendidik : untuk menjadikan karya sastra (khususnya Qasidah Burdah) sebagai salah satu rujukan dalam proses membantu individu yang dalam hal ini adalah masyarakat untuk mematangkan proses religiusitasnya. Hal ini dikarenakan dalam karya Qasidah Burdah terkandung materimateri yang dibutuhkan dalam tasawuf sebagai salah satu bagian dari kajian ajaranajaran Islam. 


\section{DAFTAR PUSTAKA}

Abdullah dan Bakry, 1991. Kamus: ArabIndonesia-Inggris; Indonesia-Arab Inggris.

Ali, Mukti. 1987. Beberapa Persoalan Agama Dewasa ini. Jakarta: Rajawali Press.

Departemen Agama, 1989. Al-Qur'an dan Terjemahnya, Surabaya: Mahkota Surabaya,

Gazalba, 1998. Islam dan Kesenian: Relevansi Islam dan Seni Budaya, Jakarta: Penerbit Pustaka al-Husna.

Goleman, Daniel. 1999. Kecerdasan Emosional. PT Gramedia Pustaka Utama. Jakarta.

Manshur, 2007, Kasidah Burdah al-Bushiry dan Popularitasnya dalam Berbagai Tradisi; Suntingan Teks, Terjemahan dan Telaah Resepsi. Yogyakarta; Universitas Gadjah Mada.

Sugijono, 2007. Memahami Penelitian Kualitatif, Bandung: CV. Alfabeta.

Zakiyah Darajat. 1991. Psikologi Agama, Jakarta: Bulan Bintang.

Zurich, 2006. Metodologi Peneltian Sosial dan Pendidikan; Teori-Aplikasi, Jakarta: Bumi U-sara.

$\underline{\text { www.amanah.or.id }}$

www.sunnirazfi.org

www.alhambraproduction.com wWw.bbc.co.uk. 